DOI: 10.15503/onis2014-357-367

\title{
EDUKACJA SEKSUALNA W GIMNAZJUM W OPINII NAUCZYCIELI
}

\author{
Aneta Baranowska, anet.bar@gmail.com \\ Uniwersytet im. Adama Mickiewicza w Poznaniu \\ Ul. Wieniawskiego 1, 61-712 Poznań
}

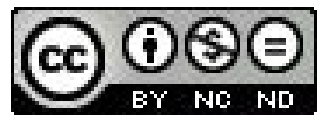

\section{STRESZCZENIE}

Celem artykułu jest zaprezentowanie, na podstawie wyników badań własnych, opinii nauczycieli przedmiotu „wychowanie do życia w rodzinie" na temat jednej z najbardziej kontrowersyjnych dziedzin współczesnej edukacji - edukacji seksualnej prowadzonej w gimnazjum. W oparciu o wypowiedzi udzielone przez respondentów przedstawione zostały treści realizowane na zajęciach z edukacji seksualnej, opinie nauczycieli na temat: modeli edukacji seksualnej, współpracy z rodzicami, organizacij zajęć z edukacji seksualnej oraz warsztatu pracy edukatorów.

Słowa kluczowe: młodzież, edukacja seksualna, szkoła, nauczyciel

Sex education in high school in the opinions of teachers

\section{Abstract}

The purpose of this article is to present, on the basis of own research results, opinions of teachers of "education for life in the family" about one of the most controversial areas of modern education - sex education conducted in the high school. Based on statements given by respondents we present content in sexual education classes, teachers' opinions on the topic: sex education models, collaboration with parents, organization of sex education classes and workshop educators.

Keywords: adolescence, sexual education, middle school, teacher

\section{WPROWADZENIE}

Celem artykułu jest zaprezentowanie, na podstawie wyników badań własnych, opinii nauczycieli przedmiotu wychowanie do życia w rodzinie na temat jednej z najbardziej kontrowersyjnych dziedzin współczesnej edukacji - edukacji seksualnej prowadzonej w gimnazjum.

Jednym z fundamentalnych praw każdego człowieka jest prawo do seksualności, rozumianejjako „całokształt doznań i przeżyć związanych z odczuwaniem i realizacją potrzeby seksualnej, stanowiącej kompilację indywidualnych biopsychospołecznych cech osoby, których kombinacja przejawia się realizacją swoistej biografii seksualnej””.1. Seksualność człowieka jest jednym z aspektów jego egzystencji, dlatego też, by nie zatracić jej specyfiki, należy rozpatrywać ten termin w szerokim kontekście, nie tylko biologicznym i fizjologicznym, ale również psycho-społecznym².

Seksualność człowieka, zdaniem Zygmunta Freuda, widoczna jest już w okresie niemowlęcym, kiedy to kilkutygodniowe dziecko wykorzystuje swoje możliwości motoryczne i sensoryczne do zaspokojenia popędu seksualnego ${ }^{3}$. W tej fazie, nazwanej przez twórcę psychoanalizy oralna, dziecko przejawia swoją seksualność przez ssanie, cmokanie czy szukanie sutka matki. W okresie poniemowlęcym, czyli w fazie analnej dziecko zaspokaja swoje popędy seksualne poprzez wydalanie kału, który jawi mu się jako coś cennego, wartościowego. Na etapie przedszkolnym, w fazie fallicznej zaobserwować możemy duży progres w rozwoju seksualnym. W tym okresie dzieci przejawiają już pewne zachowania seksualne takie jak: zachowania masturbacyjne, orientacyjne, interakcyjne, twórcze, a także pierwsze miłości. W okresie wczesnoszkolnym nie obserwuje się nowych form aktywności seksualnej. W tym czasie pogłębia się i ulega zakończeniu proces identyfikacji z płcia, dziewczynki i chłopcy intensywnie uczą się ról związanych z niąُ

Jednak dopiero w okresie adolescencji rozwój erotyczny osiaga swoje apogeum. W tym czasie młodzi ludzie zaczynają uświadamiać sobie własne potrzeby, budzi się u nich podniecenie seksualne oraz gotowość do zaspakajania go i tworzenia bliskiej więzi z drugą osobą. U nastolatków zaczynają być widoczne pierwsze formy aktywności seksualnej: masturbacja, necking, petting, z czasem młodzież podejmuje również współżycie seksualne. Przyczyną wczesnej inicjacji seksu-

1 K. Waszyńska, Biograficzne uwarunkowania życia seksualnego, Poznań 2009, s. 37.

2 Tamże.

3 M. Przetacznik- Gierowska, M. Tyszkowa, Psychologia rozwoju czlowieka. Zagadnienia ogólne, T. 1, Warszawa 2001, s. 196.

4 M. Jósewicz, Przedszkolaki i seksualność, ,Wychowanie w Przedszkolu” 2007, nr 9, s. 21. 
alnej jest przede wszystkim szybki rozwój biologiczny adolescentów. Niestety, za biologicznymi zmianami nie nadążają te emocjonalne, psycho- społeczne i intelektualne, co sprawia, że nastolatkowie nie są jeszcze w pełni gotowi, by dojrzale radzić sobie z problemami natury erotycznej, dlatego też ich zachowania seksualne coraz częściej bywają traktowane w kategoriach problemu społecznego ${ }^{5}$. Współcześnie więc osoby zaangażowane w proces wychowania młodego pokolenia zwracają uwagę na konieczność przeciwdziałania reperkusjom wynikającym z podejmowanych przez adolescentów zachowań. Jednym ze sposobów zapobiegania negatywnym implikacjom płynącym ze stylu życia młodej generacji jest edukacja seksualna.

\section{EDUKACJA SEKSUALNA}

Edukacja seksualna to „działanie skierowane do dzieci, młodzieży i dorosłych, związane z płciowością człowieka, dotyczące zdrowia seksualnego i reprodukcyjnego, polegające na dostarczaniu wiedzy na temat seksualności w różnych fazach życia człowieka, uczeniu umiejętności wartościowania postaw, kształtowaniu zachowań prozdrowotnych"6. Ta dziedzina edukacji powinna obejmować wiele zagadnień, a ich zakres i kolejność muszą wynikać z prawidłowego rozwoju psychoseksualnego jej odbiorców?

WHO za nadrzędne cele edukacji seksualnej uważa:

- $\quad$ kreowanie pozytywnej postawy wobec seksualności,

- uwzględnienie złożonych uwarunkowań i czynników determinujących seksualne zachowanie zachowania, relacje i satysfakcje,

- $\quad$ przeciwdziałanie dyskryminacji, izolacji, segregacji w zakresie seksualności,

- zmiany legislacyjne wymierzone przeciw różnym formom wykorzystywania seksualnego, gwarantujące dostęp do terapii seksualnej i brak dyskryminacji ze względu na płeć, wiek, orientację seksualna, niesprawność, stan zdrowia,

- przeciwdziałanie chorobom przenoszonym droga płciowa,

- uwzględnianie specyfiki tradycji kulturowych społeczeństwa8.

W literaturze przedmiotu wyróżnia się trzy podstawowe rodzaje edukacji seksualnej: typu A (program restrykcyjny), typu B (model permisywny) oraz typu C (model miarkowany reformistycznie - tzw. model złotego środka). Celem pierwszego z nich jest uczenie społecznych, psychologicznych i zdrowotnych korzyści wynikających z powstrzymywania się od współżycia. Wysiłki nauczycieli koncentrują się na zapobieganiu, ograniczaniu, powstrzymywaniu lub odraczaniu aktywności seksualnej poprzez ostrzeganie i odstraszanie9. Edukatorzy uświadamiają ponadto uczniom, że wstrzemięźliwość jest najpewniejszym sposobem zapobiegania chorobom wenerycznym i niechcianym ciążom. Czystość seksualna nie jest tu ujmowana tylko jako powstrzymywanie się od współżycia, ale także jako rozumne i wolne zintegrowanie przez jednostkę płciowości ciała z jej sferą duchową ${ }^{10}$. W praktyce program ten przewiduje również realizację zagadnień z obszaru profilaktyki chorób przenoszonych drogą płciowa, przede wszystkim AIDS, nikotynizmu, alkoholizmu, narkotyków, wczesnej inicjacji seksualnej, agresji wśród młodzieży, sekt czy pornografii. Duży nacisk kładzie się także na ochronę rodziny, która traktowana jest jako podstawowe i najlepsze środowisko rozwoju. Za realizacją takiego modelu edukacji seksualnej opowiada się Kościół Katolicki ${ }^{11}$.

Model permisywny, inaczej biologiczna edukacja seksualna skupia się głównie na przekazywaniu wiadomości dotyczących anatomii i fizjologii układu płciowego i dostarczaniu uczniom jak największej ilości informacji na temat środków antykoncepcyjnych, zupełnie pomijając przy tym wartości etyczne i prorodzinne ${ }^{12}$. Głównym zadaniem edukacji seksualnej typu B jest obalenie wszelkiego tabu, wyzwolenie się z przesądów i ograniczeń $\mathrm{w}$ dziedzinie seksualności oraz nieskrępowane życie płciowe. Aktywność seksualną traktuje się w kategoriach niezbędnego środka do osiagnnięcia szczęścia i pełnej satysfakcji życiowej. Zwolennicy tego modelu uważają także, że seks i prokreacja nie muszą iść w parze, dlatego

5 M. Beisert, Seksualność wżyciu człowieka, Poznań 2003, s. 160

6 A. Długołęcka, Seksualność - wybrane zagadnienia, [w:] B. Woynarowska (red.), Edukacja zdrowotna. Podręcznik akademicki, Warszawa 2007 , s. 348.

7 Tamże.

8 Tamże.

9 K. Borzucka-Sitkiewicz, Edukacja seksualna, [w:] E. Syrek (red.), Edukacja zdrowotna, Warszawa 2009, s. 159.

10 K. Urban, Edukacja seksualna ABC, ,Wychowawca” 2009, nr 4, s. 10.

11 J. Augustyn, Religijny wymiar wychowania seksualnego, ,Wychowawca” 2007, nr 7-8, s. 16.

12 K. Urban, Edukacja..., dz. cyt., s. 10. 
opowiadają się za prawem do aborcji, tłumacząc to promowaniem odpowiedzialności i świadomego rodzicielstwa ${ }^{13}$.

Permisywny model edukacji seksualnej ma wiele wad. W literaturze przedmiotu najczęściej zwraca się uwagę na to, że może on prowadzić do traktowania drugiego człowieka w sposób przedmiotowy, wyłącznie w kategoriach obiektu pożądania. Podkreśla się również fakt wpajania uczniom tylko konsumpcyjnego aspektu współżycia seksualnego, co w efekcie może opóźniać osiągnięcie dojrzałości seksualnej i zwiększyć prawdopodobieństwo wystąpienia tzw. dezintegracji seksualnej. Polega ono na trudnościach w kontrolowaniu swojego popędu płciowego, podejmowania aktywności seksualnej bez zaangażowania emocjonalnego, różnorodnych zaburzeń seksualnych powstających na skutek zbyt wczesnego bądź nieprawidłowego podejmowania aktywności płciowej ${ }^{14}$.

Modelowym przykładem państwa, w szkołach którego prowadzona jest biologiczna edukacja seksualna jest Wielka Brytania. Dzieci w tym kraju już w wieku 12 lat otrzymują darmowe prezerwatywy, normą stało się też przepisywanie 10-letnim dziewczynkom tabletek antykoncepcyjnych, podobnie zresztą jak udostępnianie im bezpłatnych środków wczesnoporonnych. Ponadto na lekcjach dzieci uczą się technik seksu oralnego, nauczyciele wyświetlają im filmy pornograficzne w celu poznania różnych pozycji seksualnych. Państwo to spośród wszystkich krajów europejkkich ma najwyższy wskaźnik, jeśli chodzi o ilość młodocianych matek. Coraz więcej Brytyjczyków zmaga się z chorobami przenoszonymi drogą płciowa, rośnie także liczba dzieci poczętych poza małżeństwem, rozwody również nie należą tu do rzadkości ${ }^{15}$.

Ostatni model edukacji seksualnej - model umiarkowany reformistycznie łączy wcześniej opisany model A i B, bazując na sześciu podstawowych zagadnieniach: wiedzy biologicznej na temat ludzkiej prokreacji, informacji dotyczących rozwoju płciowego, wiadomości na temat zapobiegania wykorzystywaniu seksualnemu, informacji na temat kontroli urodzeń, faktów dotyczących aborcji oraz informacji na temat środków antykoncepcyjnych oraz ich dostępności ${ }^{16}$.

Współcześnie widząc słabe strony zarówno wychowania do abstynencji i permisywnego modelu edukacji seksualnej propaguje się ideę wartości prorodzinnych i seksualnych człowieka według tzw. metody „złotego środka”, w której podstawowym celem jest wszechstronne przygotowanie dzieci i młodzieży do małżeństwa i życia w rodzinie. Podejście to ujmuje jednostkę w aspekcie biologicznym, psychicznym, społecznym i etycznym. Nauczyciele realizujący ten program edukacji seksualnej dążą do kształtowania u uczniów poczucia odpowiedzialności za podejmowane decyzje oraz budowania właściwych systemów wartości ${ }^{17}$. Programy umiarkowanie-reformistyczne prezentują tym samym relatywistyczne podejście do aktywności seksualnej człowieka - mimo postulowania pozytywnego stosunku do niej, nie traktują jej w kategoriach osobistego szczęścia. Krytyce wielu restrykcyjnych norm ingerujących w życie intymne towarzyszy troska o działania profilaktyczne. Edukatorzy realizujący ten program podkreślaja że rozpoczęcie współżycia seksualnego powinno iść w parze z dojrzałościa, wzajemną miłościa, wiedzą dotyczącą antykoncepcji oraz znajomością oczekiwań i potrzeb partnera. Każda metoda zapobiegania ciąży jest $\mathrm{w}$ tym modelu akceptowana, zarówno $\mathrm{w}$ związkach małżeńskich jak i pozamałżeńskich ${ }^{18}$.

W polskiej szkole edukacja seksualna odbywa się w ramach zajęć z „wychowania do życia w rodzinie". Nazwa przedmiotu nie jest przypadkowa i wskazuje, że kwestie poruszane na lekcjach nie ograniczają się tylko i wyłącznie do omawiania zagadnień związanych z seksualnością, ale także dotyczą nierozerwalnych z nią problemów moralnych i etycznych ${ }^{19}$. "Wychowanie do życia w rodzinie” realizowane jest zgodnie z rozporządzeniem z 17.02.2012 $\mathrm{r}$. w sprawie sposobu nauczania szkolnego oraz zakresu treści dotyczących wiedzy o życiu seksualnym człowieka, o zasadach świadomego i odpowiedzialnego rodzicielstwa, o wartości rodziny, życia w fazie prenatalnej oraz metodach i środkach świadomej prokreacji zawartych w podstawie programowej kształcenia ogólnego.

„Wychowanie do życia w rodzinie" odbywa się w klasach V i VI szkoły podstawowej, a także w gimnazjach, zasadniczych szkołach zawodowych, liceach ogólnokształcących, liceach profilowanych, w klasach I-III technikum. Zajęcia te realizowane są zarówno w szkołach masowych jak i specjalnych, publicznych i niepublicznych ${ }^{20}$

Na przedmiot ten przeznacza się w każdym roku szkolnym 14 godzin lekcyjnych. Dziewięć z nich prowadzona jest

\footnotetext{
13 K. Borzucka-Sitkiewicz, dz. cyt., s. 159.

14 M. Komorowska-Pudło, Ważna dziedzina: wychowanie do życia w rodzinie, „Wychowawca” 2008, nr 3, s. 7.

15 K. Urban, Edukacja..., dz. cyt., s. 11.

16 K. Urban, Trzy rodzaje edukacji seksualnej, ,Wychowawca” 2007, nr 7-8, s. 24.

17 M. Komorowska-Pudło, dz. cyt., s. 7.

18 K. Borzucka-Sitkiewicz, dz. cyt., s. 160.

19 E. Ozimek, D. Jackowiak, Wychowanie do życia w rodzinie: program nauczania dla klas gimnazjalnych, Warszawa 1999, s. 7.

20 Rozporządzenie Ministra Edukacji Narodowej z 17.02.2012 r. zmieniające rozporządzenie w sprawie sposobu nauczania szkolnego oraz zakresu treści dotyczących wiedzy o życiu seksualnym człowieka, o zasadach świadomego i odpowiedzialnego rodzicielstwa, o wartości rodziny, życia w fazie prenatalnej oraz metodach i środkach świadomej prokreacji zawartych w podstawie programowej kształcenia ogólnego (Dz.U. $2012 \mathrm{nr} 0$ poz. 300).
} 
z udziałem całej klasy, natomiast pozostałe pięć z podziałem na grupy dziewcząt i chłopców. Zajęcia organizowane są w oddziałach lub w grupach międzyoddziałowych liczących nie więcej niż 28 uczniów. Wychowanie do życia w rodzinie nie jest już realizowane z godzin do dyspozycji dyrektora szkoły jak to miało miejsce jeszcze w ostatnich latach ${ }^{21}$

Udział w zajęciach ma charakter dobrowolny. Oznacza to, że uczeń pełnoletni nie musi w tych lekcjach uczestniczyć, jeśli zgłosi dyrektorowi szkoły pisemną rezygnację. Ta sama zasada dotyczy uczniów niepełnoletnich, tyle, że w tym przypadku na składanym oświadczeniu wymagany jest podpis ich opiekunów prawnych. Zajęcia te nie podlegają ocenie i nie mają wpływu na promocję ucznia do następnej klasy ani na ukończenie szkoły, w przypadku, gdy znajduje się on w ostatniej klasie ${ }^{22}$.

W polskich szkołach zajęcia z wychowania do życia w rodzinie mogą prowadzić osoby, które ukończyły studia wyższe z zakresu nauk o rodzinie lub odpowiednie studia podyplomowe czy kursy kwalifikacyjne zgodne z treściami programowymi. Przed osobami, prowadzącymi zajęcia z edukacji seksualnej stawianych jest coraz więcej wymagań. Współcześnie postuluje się, aby nauczyciel przedmiotu wychowanie do życia w rodzinie był bardzo dobrze przygotowany merytorycznie, a więc posiadał dużą wiedzę z wielu dziedzin nauki, takich jak: psychologia (fizyczny, psychiczny i społeczny rozwój człowieka), pedagogika (metody, formy, środki dydaktyczne), medycyna (seksuologia, ginekologia, dermatologia), socjologia, antropologia, etyka, wiedza o kulturze itp. Przydatna jest także wiedza wynikająca z doświadczenia w pracy z młodzieża, przede wszystkim ta powstała w wyniku własnych, dobrych i pogłębionych relacji z uczniami. Niezbędna okazać się może również znajomość trendów, popularnych czasopism czy książek dla nastolatków. Prowadzący zajęcia powinien także umieć oddzielić wiedzę od własnych doświadczeń życiowych i poglądów. Chodzi o to, by przedstawiał młodzieży różne alternatywy - nie tylko te, które w jego przekonaniu wydają się uniwersalne i najlepsze. Na przykład na lekcji dotyczącej antykoncepcji nauczyciel powinien przedstawić uczniom wszystkie metody zabezpieczające przed ciąża, z ich wadami i zaletami, a nie ograniczać się wyłącznie do tych, które są w jego świadomości skuteczne ${ }^{23}$.

Ponadto nauczyciel powinien umieć zadbać o atmosferę otwartości, szczerości, zaufania i dyskrecji, posiadać empatię i być wrażliwym na drugiego człowieka ${ }^{24}$. Znawcy problematyki edukacji seksualnej do istotnych zachowań nauczyciela zaliczają ponadto: bezpretensjonalne odnoszenie się, wykazywanie zrozumienia i akceptacji, optymizm, dystans, poczucie humoru, unikanie zadawania zbyt wielu pytań, utwierdzanie uczniów w poczuciu własnej wartości, ale także szanowanie odmiennych poglądów i unikanie stereotypowego myślenia na temat płci, seksualności, wystrzeganie się moralizowania i pouczania, świadome budowanie własnego pozytywnego wizerunku kobiecości/męskości (oczywiście bez popadania w skrajność), zachowywanie pokory oraz przestrzeganie pewnych granic, np. unikanie opowiadania o swoim życiu intymnym ${ }^{25}$.

Wspótcześnie ta dziedzina edukacji wzbudza wiele kontrowersji i obaw. Od lat toczą się zażarte dyskusje wokół jej celów, zakresu, podmiotów uczestniczących i prowadzących oraz planowanych efektów. Z edukacją seksualną wiąże się wiele dylematów takich jak: czy dzieciom i młodzieży należy przekazywać wiedzę dotycząca ludzkiej seksualności?, Kto powinien to czynić: rodzice czy szkoła?, Od jakiego wieku należy edukować dzieci w tej sferze? Jakie wartości powinna promować edukacja seksualna? Czy ta dziedzina edukacji nie przyczynia się do wcześniej inicjacji seksualnej młodych ludzi? ${ }^{26}$ Nie ulega jednak wątpliwości, niezależnie od powyższych kontrowersji, że ogromna ilość przeróżnych zjawisk życia codziennego, takich jak: nieustające występowanie problemu ciąż nastolatek, pojawienie się coraz większej liczby chorób przenoszonych drogą płciowa, epidemia HIV i AIDS, liberalizm w odniesieniu do sfery seksualnej człowieka, problem wykorzystywania seksualnego, zjawiska prostytucji, pornografii oraz dynamiczny rozwój Internetu, powodujaccy możliwość zawierania kontaktów przez małe dzieci z nieznajomymi osobami, dostarcza nam mocnych argumentów za koniecznością prowadzenia realistycznej i dostosowanej do wieku odbiorców edukacji seksualnej ${ }^{27}$. Edukacja seksualna powinna odbywać się przede wszystkim w domu rodzinnym, jednak rodzice rzadko wywiązują się z tego obowiązku, zrzucając niekiedy całą odpowiedzialność w tej kwestii na szkołę. Czy zatem ta instytucja należycie realizuje postawione przed nią zadania związane z dostarczaniem młodzieży rzetelnej wiedzy o seksualności człowieka? Chcąc znaleźć odpo-

21 Tamże.

22 Tamże.

23 A. Długołęcka, dz. cyt., s. 371.

24 M. Kozakiewicz, Z. Lew-Starowicz, Przysposobienie do życia w rodzinie, Warszawa 1987, s. 28

25 Tamże, s. 385 .

26 E. Kasperek-Golimowska, Edukacja seksualna jako forma ochrony i promocji zdrowia seksualnego, [w:] K. Waszyńska, Z. Lew-Starowicz (red.), Przemiany w spoleczeństwie wspótczesnym: teoria i rzeczywistość, Poznań 2012, s. 87.

27 A. Dhugołęcka, dz. cyt. s. 386. 
wiedź na to pytanie przeprowadziłam badania, których głównym celem było poznanie opinii uczniów i nauczycieli na temat edukacji seksualnej realizowanej w gimnazjum. W artykule zostanie przedstawiona część wyników empirycznych dociekań-opinie nauczycieli.

\section{ZAŁOŻENIA METODOLOGICZNE BADAŃ WŁASNYCH}

Sformułowane przed badaniami cele szczegółowe obejmowały następujące zagadnienia:

1. Przedstawić opinie nauczycieli na temat treści realizowanych na zajęciach z edukacji seksualnej.

2. Zbadaćjaki model edukacji seksualnej preferują badani edukatorzy.

3. Poznać $\mathrm{w}$ jaki sposób nauczyciele oceniają organizację zajęć $\mathrm{z}$ edukacji seksualnej zawartą $\mathrm{w}$ rozporządzeniu w sprawie sposobu nauczania szkolnego oraz zakresu treści dotyczących wiedzy o życiu seksualnym człowieka, o zasadach świadomego i odpowiedzialnego rodzicielstwa, o wartości rodziny, życia w fazie prenatalnej oraz metodach i środkach świadomej prokreacji zawartych w podstawie programowej kształcenia ogólnego.

4. Zbadać jak w opinii nauczycieli wygląda warsztat ich pracy.

5. Poznać opinie nauczycieli na temat ich współpracy z innymi nauczycielami i rodzicami uczniów w kwestii edukacji seksualnej.

Dobór badanej próby był celowy. Wywiady zostały przeprowadzone z 18 nauczycielkami prowadzącymi na co dzień zajęcia z edukacji seksualnej (przedmiotu „wychowanie do życia w rodzinie”) w gimnazjach. Wśród badanych edukatorek znalazły się zarówno humanistki, jak i osoby specjalizujące się w naukach ścisłych i przyrodniczych. Co trzecia (33,3\%) badana nauczycielka z wykształcenia jest biologiem. 28\% edukatorek (5 osób) ukończyła studia historyczne i studia podyplomowe z wiedzy o społeczeństwie. $11 \%$ respondentek ( 2 osoby) to absolwentki filologii polskiej. Tyle samo badanych również ukończyła fizykę. $11 \%$ badanych (2 osoby) to nauczycielki wychowania fizycznego, a $6 \%$ badanych edukatorek (1 osoba) uczy plastyki. Każda z badanych nauczycielek ukończyła studia podyplomowe z zakresu nauk o rodzinie. Ze względu na niewielką grupę badawczą badania nie są reprezentatywne tzn. ich wyników nie można uogólniać na szerszą populację.

Zastosowaną w badaniach metodą był sondaż diagnostyczny, techniką zaś wywiad. Zdecydowano się posłużyć tą techniką ponieważ umożliwia ona badanie faktów, opinii i postaw danej zbiorowości, a więc tego wszystkiego co zamierzano zweryfikować. Dodatkowo pozwala również na pogłębione poznanie środowiska wychowawczego oraz możliwość jego zmiany ${ }^{28}$. W badaniach zastosowano wywiad nieskategoryzowany (przewaga pytań otwartych), jawny (respondenci poinformowani zostali o celach, charakterze i przedmiocie rozmowy) oraz indywidualny. Narzędziem badawczym był kwestionariusz wywiadu, składający się z 22 pytań, głównie otwartych.

Warto nadmienić, że przedstawione w tym artykule wyniki badań stanowią część znacznie obszerniejszych dociekań empirycznych, w których badano także opinie młodzieży gimnazjalnej na temat szkolnej edukacji seksualnej.

\section{ANALIZA WYNIKów BADAŃ WŁASNYCH}

Jak wynika z badań każda z badanych nauczycielek uważa, że zajęcia z edukacji seksualnej powinny odbywać się w szkole. Podkreślają one, że seksualność jest jednym z podstawowych aspektów życia człowieka i w związku z tym należy zaznajamiać młodzież z jej zagadnieniami, aby mogła prawidłowo się rozwijać:

Jestem za edukacja seksualna w szkole. Młodzież musi być woyposażona w określony zasób wiedzy dotyczacej seksualności, rodziny. W przecizonym razie nie poradzi sobie wo życiu, będzie miała trudności w relacjach damsko- męskich (Natalia).

Edukatorki zwracają również uwagę na ogromny wpływ środków masowego przekazu, w tym głównie Internetu w kształtowaniu u młodych ludzi postaw związanych z seksualnością. Ich zdaniem nie zawsze media dostarczają adolescentom rzetelnych wiadomości, co wielokrotnie w ich odczuciu widać na lekcjach z edukacji seksualnej, kiedy młodzież ma możliwość wykazania się swoją „,wiedzą":

Uważam, że gimnazjaliści bardzo mało wiedza o seksie. Niby to popisuja się tą swoja wiedza, ale czasem mnie dreszcze przechodza. jak stysze, że np. tabletke gwałtu można rozpoznać ww napoju, bo zmienia ona jego smak. Jak się pytam skąd to wiecie to odpowiadaja mi oczywiście, że z Internetu! Kiedyśs czytałam w wolnej chwili kilka stron na temat seksu, które w nim się znajdują i po paru minutach ich czytania miałam serdecznie dość. Gdyby nie zajęcia z "wychowania do życia w rodzinie" to ja nie wiem co z tych ludzi by wyrosto (Barbara).

Nauczycielki uważają także, że współcześnie gimnazjaliści narażeni bywają na wiele niebezpieczeństw, którym z ra-

28 T. Pilch, T. Bauman, Zasady badań pedagogicznych, Warszawa 2001, s. 91.

OGRODY NAUK I SZTUK NR 2014 (4) 
cji młodego wieku, a przede wszystkim małej dojrzałości psychiczno-emocjonalnej i braku poczucia odpowiedzialności mogą nie umieć się przeciwstawić. Ich zdaniem więc, koniecznym wydaje się uświadomienie młodym ludziom zagrożeń XXI w., czemu ma właśnie służyć profesjonalnie prowadzona edukacja seksualna w szkole:

Każdy z nas oglada telewizjęésedzi bieżace woydarzenia, wie więc co się na świecie dzieje. Ile młodych ludzi jest już po inicjacji, dla ilu aktywność seksualna kończy się nieplanowana ciaża. To wszystko jest przerażajace. Uważam, więc, że trzeba o takich rzeczach mówić, robić wszystko, by byto ich jak najmniej (Małgorzata).

Kiedyśs oglądałam film "Galerianki", ten o prostytuujacych się gimnazjalistkach. Bytam w szoku jak go zobaczyłam. Straciłam wiare w to, co robie, no bo skoro zjawisko prostytucji istnieje pomimo, że my edukatorzy przestrzegamy przed nim młodych ludzi to jak widzié́ dalej sens swojej pracy? Nie poddałam się jednak i powiedziałam sobie, że będę o tych wszystkich zagrożeniach mówić jak najwięcej, by żadna z moich uczennic nie musiała w przysztości zniżać się do takiego poziomu jak bohaterki tego filmu (Aleksandra).

Jeszcze inne nauczycielki zwracają uwagę na niski poziom edukacji seksualnej realizowanej w domach uczniów:

Wiem, że dziś w domach o seksie się nie rozmawia, zresztą o wielu innych rzeczach też nie. Jak zapytałam się kiedyś uczniów czy ich rodzice rozmawiali z nimi o życiu seksualnym to zaczeli się śmiać mówią, że taka sytuacja w ich życiu nigdy nie miała miejsca inie spodziewaja się by coś miało się w tej kwestii zmienić. Gdzie więc ta młodzież ma się uczyć o metodach antykoncepcji czy chorobach wenerycznych? W szkole ostatnia nadzieja. Nie twierdzę oczywiście, że jesteśmy tu w stanie nauczyć młodziė̇ wszystkiego i wszystkiemu zapobiec, ale wiem, że wielu uczniom te zajęcia dużo dają i choćby nawet dla garstki z nich musi być możliwość uczestnictwa w lekcjach

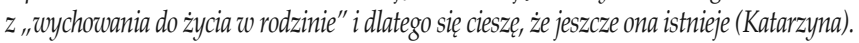

W trakcie zajęć z edukacji seksualnej nauczycielki zaznajamiają uczniów z następującymi zagadnieniami: budową i funkcjonowaniem narządów płciowych, metodami planowania rodziny, rolą rodziny w życiu człowieka, przyjaźnia, miłościa, działaniem alkoholu i narkotyków na organizm człowieka, higieną osobista, chorobami przenoszonymi drogą płciowa, podstawowymi problemami okresu dojrzewania, motywami i konsekwencjami podejmowania wczesnej inicjacji seksualnej, zmianami fizycznymi i psychicznymi okresu adolescencji, relacjami małżeńskimi, rolą rodziny w życiu człowieka, podobieństwami i różnicami między przyjaźnią a miłościa, zachowaniami asertywnymi, budową i funkcjonowaniem układów rozrodczych: męskiego i żeńskiego.

Z przedstawionych danych wynika, że edukatorki prowadzące w gimnazjach przedmiot „wychowanie do życia w rodzinie" starają się omawiać z uczniami wiele tematów. Niestety brakuje wśród nich wielu ważnych treści, takich jak: przebieg ciąży, opieka nad dzieckiem, formy aktywności seksualnej np. petting czy necking, homoseksualizm czy nadużycia seksualne. Badane nauczycielki przyznały, że nie podejmują w trakcie swoich zajęć tych kwestii. Tymczasem są to zagadnienia bardzo ważne. Należy bowiem uświadamiać młodzieży, że oprócz współżycia seksualnego istnieją także inne formy aktywności seksualnej. Gdy nie zostanie to zrobione, młodzi ludzie będą szukać informacji na ten temat $\mathrm{w}$ innym miejscu np. $\mathrm{w}$ Internecie. Kwestie związane $\mathrm{z}$ homoseksualizmem również powinny być podejmowane, ponieważ młodzi ludzie w okresie adolescencji często podejmują kontakty seksualne z osobami tej samej płci. Nie świadczą one jednak o odmiennej orientacji seksualnej, ale o potrzebie eksperymentowania ze swoim ciałem ${ }^{29}$. Należy więc uświadamiać nastolatkom, że taka forma aktywności seksualnej nie powinna wiązać się z wyrzutami sumienia czy niższą samooceną. Zagadnieniom dotyczącym opieki nad dzieckiem również powinno się poświęcać więcej uwagi, ponieważ opiekuńcza funkcja rodziny jest jednym z najważniejszych elementów funkcjonowania rodziny, a celem przecież zajęć z edukacji seksualnej realizowanych w szkole jest właśnie przygotowanie do życia w rodzinie. Patrząc na niepokojące dane mówiące o tym ile współcześnie młodych dziewcząt zachodzi w ciążę, ważne jest także podejmowanie kwestii związanych z przebiegiem samej ciąży, a więc jak rozwija się dziecko, na co trzeba szczególnie zwracać uwagę, w jaki sposób należy dbać o siebie etc. Jeżeli nawet treści te nie okażą się przydatne w najbliższej przyszłości, to z pewnością zostaną wykorzystane za kilka czy kilkanaście lat, a więc czas poświęcony na ich omawianie nie zostanie zmarnowany. Warto również odnieść się do postulatu, mówiącego o tym, że na zajęciach z edukacji seksualnej powinny być realizowane zagadnienia związane z nadużyciami seksualnymi. Współcześnie, na skutek większej demoralizacji społeczeństwa coraz częściej dochodzi do różnych patologicznych zjawisk np. prostytucji czy gwałtó $w^{30}$. W związku z tym należy młodych ludzi uczulać na te zjawiska.

Przy doborze treści kształcenia większość badanych nauczycielek, bo aż 83\% (15 osób) kieruje się podstawą programowa. Edukatorki ufają kompetencjom osób, które je redaguja, a przede wszystkim Ministerstwu Edukacji Narodowej, które dopuszcza program do użytku:

29 I. Obuchowska, A. Jaczewski, Rozwój erotyczny, Warszawa 1982, s. 165.

30 I. Pospiszyl, Patologie spoteczne, Warszawa 2003, s. 43. 
Z każdego przedmiotu mamy podstawe programowa w wersii takich ksiażeczek. Wymaga od nas ona, aby na zajęciach były poruszane takie a nie inne zagadnienia więc to robię. Zreszta jestem potem z tego rozliczana więc nie za bardzo mam woybór (Renata).

Takie programy opracowuja wykształceni ludzie, pedagodzy, psycholodzy więc wiedza co proponuja. Zreszta Ministerstwo nad tym wszystkim czuwa (Paulina).

Prawie 2/5 respondentek (7 osób) przy doborze treści kształcenia kieruje się własną intuicją. Edukatorki, zwłaszcza te mające bogate doświadczenie pedagogiczne i długi staż pracy, są zdania, że potrafią same selekcjonować proponowane przez Ministerstwo zagadnienia i wybierać te, które w ich odczuciu najbardziej przydadzą się ich uczniom:

Przegladam program nauczania i zdarza się, że opuszcze jakiś temat, który wydaje mi się mało ważny czy atrakcyjny. Nie na wszystko wystarcza też czasu (Ewa).

Połowa badanych nauczycielek (9 osób) przy selekcjonowaniu treści kształcenia zwraca również uwagę na zainteresowania uczniów:

Biorę pod uwagę to, co uczniowie chca omawiać. Wydaje mi się to ważne (Ilona).

$17 \%$ nauczycielek ( 3 osoby) przyznaje również, że wpływ na to jakie treści poruszy danego dnia z gimnazjalistami mają obejrzane przez nie programy telewizyjne czy przeczytane artykuły, zwłaszcza te zamieszczone na łamach młodzieżowych czasopism:

Zdarza się, że coś mnie natchnie, coś przeczytam w tych kolorowych gazetach dla dziewwczat, obejrzę w telewizji i robię potem z tego dyskusję, aby zobaczyć jak uczniowie postrzegaja pewne rzeczy (Karolina).

Wszystkie badane edukatorki preferują model złotego środka, inaczej określany mianem edukacji seksualnej typu C. Badane widzą szereg jego zalet:

W tym modelu kładzie się duży nacisk na wzajemna odpowiedzialność partnerów, a to powinno być podstawa związku (Agnieszka).

Podoba mi się w tym modelu to, że jednostka ma tu wybór - nic nie jest jej narzucane z góry np. to, że ma nie wspótżý́, jak mówwi edukacja seksualna typu A, czy to, że wtaśnie musi się kochać z partnerem, co podkreśla się w modelu typu B. Wybór jest ważny - pokazujemy dwie strony medalu, ale to jednostka ostatecznie decyduje o tym, który wybierze (Wanda).

Duży nacisk w tym modelu kładzie się na tolerancję, szanuje się różne wartości uczniów (Magdalena).

W modelu C podkreśla się dużą wagę więzi emocjonalnej między partnerami, uczy się szanowania ludzkich postaw, rodziny, odpowiedzialności za swoje zachowanie (Ewa).

Prawie 4/5 badanych edukatorek (14 osób) widzi konieczność zwiększenia liczby godzin przeznaczonych na realizację zajęć $\mathrm{z}$ edukacji seksualnej w szkole. Ich zdaniem jedna godzina w tygodniu przez jeden semestr to zdecydowanie za mało, by móc w pełni zrealizować podstawę programową i podjąć także tematy proponowane przez uczniów:

Co to jest to marne 14 godzin na semestr. Nie da się zrealizować wszystkich trésci, bo program jest bogaty. Koniecznie trzeba troche zwiększyć liczbe godzin (Magdalena).

Nauczycielki, które opowiadają się za zwiększeniem liczby godzin przeznaczonych na realizację przedmiotu „,wychowanie do życia w rodzinie" zwracają również uwagę na brak możliwości częstej aktywizacji uczniów.

Czasem jest tak, że dwa tematy muszę przerobić na jednej lekcji, więc zdarza się, że po prostu przez te 45 minut mówię bez przerwy, a uczniowie tylko siedza i mnie stuchaja. Z drugiej jednak strony jak chciatabym, aby zrobili jakieśs ćwiczenie to znowu nie wyyrobie sie z materiatem i tak źle i tak niedobrze. Naprawdę przydałoby się więcej tych zajęć, by móc wszystko to ogarnaćc (Justyna).

Zdaniem prawie $60 \%$ tych nauczycielek (8 osób) zajęcia z edukacji seksualnej powinny odbywać się przez cały rok szkolny, natomiast ponad 2/5 tych edukatorek (6 osób) twierdzi, że wystarczyłoby tylko 5 godzin więcej.

$22 \%$ edukatorek (4 osoby) twierdzi, że dotychczasowa liczba godzin przeznaczona na zajęcia z edukacji seksualnej jest wystarczająca. Co ciekawe badane argumentują swoje opinie również poprzez odniesienie się do możliwości realizacji programu nauczania, z tym, że uważaja, że są w stanie w pełni omówić określony materiał i dlatego też, w ich odczuciu nie ma potrzeby zmieniać liczby godzin przeznaczonej na realizację przedmiotu „wychowanie do życia w rodzinie":

Nie mam problemu z wyrobieniem się z materiałem więc nie widzę potrzeby, aby tych zajęć musiałoby być więcej (Małgorzata).

Nie ma sensu na sitę szukać jakiś zagadnień do omaziania. Uczniowie męczyliby się przy tym i my nauczyciele również (Ilona).

Ten wydawać by się mogło paradoks wynika z pewnością z odmiennych podejść nauczycielek do swojej pracy. Trudno jest jednak jednoznacznie określić, które edukatorki wywiązują się lepiej z obowiązku, jakim jest przekazanie młodym ludziom rzetelnej wiedzy na temat seksualności człowieka: czy te, które nie mogą zrealizować materiału czy te, które nie mają z tym problemów. Wszystko bowiem zależy od efektywności ich nauczania.

Niewiele ponad $1 / 4$ nauczycielek (5 osób) uważa, że zajęcia z edukacji seksualnej powinny być obowiązkowe. Ich zda-

OGRODY NAUK I SZTUK NR 2014 (4) 
niem w trakcie lekcji z „,wychowania do życia w rodzinie" podejmowane są bardzo istotne kwestie dotyczące seksualności człowieka. Edukatorki uważaja, że 100\% frekwencja uczestnictwa w tych zajęciach przyczyniłaby się do podniesienia wiedzy uczniów z zakresu rozwoju seksualnego i tym samym zmniejszyłaby prawdopodobieństwo wystapienia u młodzieży ryzykownych zachowań seksualnych:

Zajęcia te powinny być obowiazkowe, ponieważ to jedyny sposób na to, by młodzi ludzie nauczyli się czegoś o życiu seksualnym. Każdy uczén nawet jeśliby przeszkadzat na lekcjach to zawsze wynióstby z tych zajẹć coś pożytecznego. A tak niektórzy celowo prosza rodziców, aby nie podpisywali zgody na ich udział w "wyychowaniu do życia w rodzinie", by mieć tylko lekcję wolna. Tak nie może być (Barbara).

Prawie $3 / 4$ nauczycielek (13 osób) twierdzi jednak, że zajęcia te nie powinny być obowiązkowe, ponieważ seksualność człowieka to bardzo delikatna sfera funkcjonowania jednostki, którą należy traktować w sposób holistyczny. Nie należy, więc patrzeć na nią tylko przez pryzmat biologiczny, ale również psychiczno-emocjonalny. W związku z tym dla niektórych uczniów podejmowanie tematów związanych z seksualnością może być krępujące:

Tematy seksualne to zawsze będa kontrowersyjne kwestie, ponieważ nie wiaża się tylko z biologia, ale także z funkcjonowaniem emocjonalnym ucznia. Do tego dochodzi jeszcze szereg różnych kwestii np. wychowanie rodzinne czy nieśmiatość ucznia. Nie sadzę, więc, że wprowadzenie obowiazkowych zajęć to dobry pomyst (Wanda).

Nauczycielki wskazując na wielorakie aspekty ludzkiej seksualności podkreślają także, że nieodłącznie wiąże się ona ze światopoglądem religijnym np. Świadkowie Jehowy nie mogą uczęszczać w zajęciach z „wychowania do życia w rodzinie" w szkole, ponieważ u nich edukacja seksualna realizowana może być tylko i wyłącznie w domu rodzinnym. W związku z tym przymuszanie uczniów do brania udziału w tych zajęciach byłoby naruszeniem praw jednostki do wolności i wyznania.

Tylko 13\% badanych edukatorek (3 osoby) uważa, że zajęcia z edukacji seksualnej powinny być oceniane. Jest to niewielka część tych nauczycielek, które opowiadają się za obowiązkowym uczestnictwem młodych ludzi w lekcjach $\mathrm{z}$ „wychowania do życia w rodzinie". Osoby te sądza, że wpłynęłoby to na większe zainteresowanie gimnazjalistów omawianymi treściami, czego egzemplifikacją może być poniższa wypowiedź:

Gdyby zajęcia te byly oceniane to uczniowie musieliby uczyć się tych treści, a więc jakieś zainteresowanie nimi by się pojawito. Coś więc z tej nauki każdy by zapamiętat i wykorzystał w życiu. Jéli się czegoś uczymy to zawsze cośz zeego zapamiętamy (Agnieszka).

Nauczycielki zwracają również uwagę, że świadomość otrzymania oceny z edukacji seksualnej przyczyniłaby się do lepszej atmosfery na zajęciach:

Gdybym postraszyła uczniów, ze zaraz zrobię kartków kę to każdy z nich by się uspokoit i zachowuywat się ciszej, co ułatwitoby mi prowadzenie lekcji. A tak nie mam w ręku tego narzędzia, co jedynie mogę krzyczé, a i tak spokój jest tylko na parę chwil (Krystyna).

Prawie 9/10 nauczycielek (16 osób) jest jednak zdania, że wiedza nastolatków z zakresu edukacji seksualnejnie powinna podlegać ocenie. Swoje odczucia tłumaczą w następujący sposób:

Myśle, że ocena z „wychowania do życia" wiaże się z obowiazkowym uczestnictwem w tych zajęciach, a nie można zmusić uczniów by chodzili na zajęcia, na których mogą czuć się skrępowani (Monika).

Nie za bardzo wiem, co miatabym oceniać. Na tych zajęciach raczej ucze pewonych postaw, samej wiedzy nie ma jakoś dużo. A nie moge przecież oceniać tego czy ktoś jest za seksem przed ślubem a ktoś przeciw (Katarzyna).

Wszystkie badane nauczycielki uważaja, że dotychczasowy układ lekcji z „wychowania do życia w rodzinie” jest zadawalający. Jak mówią:

9 lekcji razem to dobra decyzja. Pewwne kwestie należy analizować wspólnie z chtopcami i dzierwczynkami. Sa jednak tematy, które należy omawiać także osobno, by nie zawsstydzać którejś ze stron, dlatego te 5 godzin osobno także jest potrzebne (Agnieszka).

Materiat jest tak utożony, że zajęcia w pewnym momencie musza odbywać się osobno z chtopcami i osobno z dziewczynkami. Wiem, że uczniowie sa z tego zadowoleni więc nie widzępotrzeby, aby coś należało w tek kwestii zmienić (Wanda).

Edukatorki zwracają jednak uwagę na jedną słabą stronę wynikającą z podziału klasy po dziewięciu wspólnych zajęciach z edukacii seksualnej na dwie grupy:

Problem generalnie dotyczy tego, ż jak np. chłopcy maja zajęcia to dziewczynki musza wtedy siedzieć w świetlicy i na odwrót. Wiem, że uczniom zapewne jakos to nie przeszkadza, ale to jest trochę marnotrawienie czasu (Milena).

Wszystkie badane edukatorki twierdza, że zajęcia z edukacji seksualnej powinna prowadzić kobieta. Ich zdaniem kobiety są w stanie kwestie związane z seksualnością poruszać zarówno z chłopcami, jak i dziewczynkami:

Myślę, że kobiety są bardziej wrażlizusze na te sprawy (Magdalena).

Nauczyciele to przede wszystkim kobiety, więc dla chtopców jest to normalne, że i "wychowania do życia w rodzinie" uczy też kobieta. Natomiast dziewwczynki perwnie nie czutyby się za komfortowo, gdyby mężczyzna mówiit im np. o miesiaczce (Aleksandra). 
Najczęstszymi metodami nauczania stosowanymi przez nauczycielki w trakcie lekcji z edukacji seksualnej są pogadanka oraz dyskusja, stosuje je bowiem aż prawie $90 \%$ badanych (16 osób). Edukatorki wysoko cenią sobie również wykład, zwłaszcza na początku zajęć, kiedy zaznajamiają uczniów z nieznanymi im do tej pory treściami. Metodę tą wykorzystuje $83 \%$ respondentek (15 osób). Sporadycznie stosowana jest praca z tekstem - żadna ze szkół, w których uczą na co dzień respondentki nie wymaga korzystania z podręczników na zajęciach z edukacji seksualnej, ale 1/3 nauczycielek (6 osób) przynosi uczniom na lekcje artykuły, które są w ich trakcie czytane, a następnie wspólnie omawiane. Niezbyt dużą popularnością cieszą się gry dydaktyczne, stosuje je bowiem tylko niecała $1 / 5$ edukatorek (3 osoby).Z Z przedstawionych danych wynika, że nauczycielki starają się dbać podczas zajęć o wyzwalanie aktywności u uczniów. Podejście takie powinno cieszyć, bowiem nie chodzi przecież o to, aby na lekcjach z edukacji seksualnej przekazywany był tylko określony zakres wiadomości, ale także o partnerskie dochodzenie wraz z młodzieżą do pewnych opinii, wniosków. Ponadto dopuszczanie uczniów do głosu wzbudza w nich zainteresowanie omawianymi zagadnieniami i tym samym zwiększa prawdopodobieństwo osiagnięcia zamierzonych celów wychowawczych ${ }^{31}$.

Do najczęściej wykorzystywanych środków dydaktycznych w trakcie lekcji z „wychowania do życia w rodzinie” należą: filmy, plakaty, przedstawiające zazwyczaj budowę układów rozrodczych prezentacje multimedialne oraz wcześniej wspomniane artykuły. Prawie 1/4 nauczycielek (4 osoby) nie odczuwa potrzeby urozmaicania swoich zajęć materiałami naukowymi.

Jak wynika z badań prawie $3 / 4$ nauczycielek (13 osób) często, a ponad $1 / 4$ (5 osób) sporadycznie przeprowadza diagnozę potrzeb uczestników zajęć z edukacji seksualnej tzn. przed lekcjami pyta się gimnazjalistów, jakie treści chcieliby danego dnia omawiać. Niektóre z nich proszą o wyrażenie uczniowskich postulatów na forum klasy, ale większość edukatorek zachęca nastolatków do anonimowego spisywania swoich próśb na kartkach. Oznacza to, że prowadzące zajęcia są elastyczne, nie trzymają się kurczowo programu nauczania, a liczą się z tym, że uczniowie w danej chwili mogą odczuwać chęć zdobycia informacji na temat, który pierwotnie miał zostać zrealizowany w innym terminie lub pominięty w ogóle.

Według przeprowadzonych badań żadna z nauczycielek nie prosi gimnazjalistów, wykorzystując np. krótki kwestionariusz ankiety, o dokonanie oceny sposobu prowadzenia przez niego zajęć. Uważaja że nie mają za bardzo na to czasu, a poza tym uzyskane informacje niewiele by im pomogły.

Nie widzę takiej potrzeby, opinie uczniów z pewnością nie pomogłyby mi w ulepszaniu mojego warsztatu pracy (Monika).

Niestety trudno zgodzić tu się z opiniami nauczycielek, ponieważ informacje zwrotne otrzymane od uczniów pozwoliłyby im krytycznie spojrzeć na ich warsztat pracy i w razie potrzeby skłonić do pracy nad soba, co okazałoby się również cenne dla samej młodzieży.

Żadna z badanych nauczycielek nie współpracuje regularnie z nauczycielami i pieleggniarką szkolną w kwestii edukacji seksualnej. Zdaniem każdej z nich po prostu nie ma takiej potrzeby.

Mam program nauczania, którego się trzymam i nie widze potrzeby, aby rozmawiać o nim z innymi nauczycielami. Oni mają swoje zajecia, swoje problemy (Ilona).

Zdarza się, że czasem rozmawiamy z koleżankami o swoich lekcjach, ale raczej bardzo sporadycznie (Danuta).

Nie czuje sie gorsza od pielegniarki szkolnej, dlatego też nie proszę ja, aby przychodzita na zajęcia i omawiała za mnie jakiś temat. Zdarza się jednak, że jak mam jakaśs naprawdę dużą watpliwość to ją czasem o coś zapytam. Na przykład w jednym z podręczników spotkatam się z informacja, że plemniki żyją w jajowodach kobiety nawet 120 godzin, a winnej ksiażce, że tylko 72 . Nie wiedziałam, co jest prawda, bo obie publikacje miaty charakter naukowy, więc poprositam ja o sprostowanie tych informacji (Emilia).

Z powyższych danych wynika, że w szkołach każda nauczycielka odpowiada za swój przedmiot, a wspótpraca między edukatorami, jeśli chodzi o organizację procesu kształcenia ogranicza się tylko do sporadycznych rozmów. Tymczasem osoby prowadzące zajęcia z edukacji seksualnej powinny rozmawiać z innymi nauczycielami o treściach, które realizuja, powinni także szczegółowo przeanalizować tematy, które w najbliższym czasie ich koledzy będą omawiać na lekcjach wychowawczych, biologii czy religii, a więc na przedmiotach, na których często tematyka seksualności jest poruszana, w celu nie powielania niektórych zagadnien. Jest to o tyle istotne, że powtarzanie w kółko tych samych treści nudzi uczniów i powoduje brak ich zainteresowania aktywnym włączeniem się w proces dydaktyczny, o czym świadczą niecytowane w tym artykule opinie gimnazjalistów dotyczące wielokrotnego realizowania na różnych przedmiotach zagadnień związanych np. z uzależnieniami ${ }^{32}$.

Zmierzając ku końcowi warto podkreślić, że nauczyciele prowadzący zajęcia z edukacji seksualnej nie powinni ogra-

31 M. Kozakiewicz, Z. Lew-Starowicz, dz. cyt., s. 13.

32 A. Baranowska, Wychowanie seksualne w szkole - opinie gimnazjalistów, „Nowa Szkoła” 2013, nr 4, s. 37.

OGRODY NAUK I SZTUK NR 2014 (4) 
niczać się tylko i wyłącznie do pracy z uczniami, ale także współdziałać w tych kwestiach z ich rodzicami. Dlatego ważne wydaje się organizowanie cyklicznych spotkań z opiekunami adolescentów, tak by treści przekazywane w domu nie były sprzeczne z tymi dostarczanymi w szkole. Respondentki przyznają jednak, że nie współpracują z rodzicami uczniów w kwestii edukacji seksualnej, choć każda z nich widzi taką konieczność. Większość z nich twierdzi (72\%-13 osób), że nie mają na to czasu zarówno nauczyciele jak i rodzice.

Uważam, że brak czasu decyduje o tym, że nie ma, kiedy nawet zorganizować jakiegośs spotkania z rodzicami. Oni też sa zabiegani na pewno (Magdalena).

Inne badane (11\%-2 osoby) uważają, że sami rodzice nie byliby chętni do współpracy, ponieważ sami najlepiej wiedzą jak mają wychowywać $w$ tej sferze swoje dzieci.

Wielokrotnie próbowałam podjać wspótprace z rodzicami moich uczniów w kilku innych sprawach i zawsze nie wychodzito, w zwiazku z tym teraz tė̇ zapewne byłoby ciężko, zwołaszcza, że przecież tematyka spotkania byłaby dość delikatna (Alicja).

Na szczęście w szkołach 17\% respondentek (3 osób), dzięki wzięciu udziału w programie „Wyspa Skarbów” autorstwa Szymona Grzelaka, podejmowane były działania mające na celu zaangażowanie rodziców w proces wychowania do miłości ich dzieci czy profilaktykę uzależnień w obszarze seksualności. Program ten składał się z trzech elementów: mitingu z młodzieża, spotkania z rodzicami oraz szkoleniowego spotkania rady pedagogicznej. W trakcie spotkania z opiekunami nastolatków prezentowane były wyniki badań nad młodzieżą z komentarzem podpowiadającym skuteczne metody wychowania i komunikacji. Przedstawione zostały również główne tezy programu dla adolescentów. Celem tych spotkań było ułatwienie rodzicom rozmów z dziećmi na tematy, które program porusza. Spotkanie miało formę wykładu urozmaiconego pogadanką i materiałami dydaktycznymi ${ }^{33}$.

\section{KonKLUZJA}

Z przedstawionych danych wynika, że badane nauczycielki dostrzegają konieczność prowadzenia w szkole zajęć z edukacji seksualnej i starają się w związu z tym choć w niewielkim stopniu spełniać od lat pokładane w szkole nadzieje związane z przekazywaniem młodym ludziom rzetelnej wiedzy na temat ich seksualności. Empiryczne dociekania dowiodły, że respondentki za cel swojej pracy stawiają kształtowanie u młodych ludzi odpowiedzialności za podejmowane decyzje oraz budowanie właściwego systemu ich wartości, czego dowodem jest preferowanie przez nich edukacji seksualnej typu C. Nauczycielki uważaja, że zamierzone przez nich cele zostaną osiągnięte tylko dzięki aktywizującym metodom nauczania, dlatego też w trakcie zajęć z przedmiotu „wychowanie do życia w rodzinie" dbają o wyzwalanie wśród swoich uczniów aktywności i zaangażowania. Starają się także przekazywać gimnazjalistom wiedzę dotyczącą przeróżnych zagadnień, biorąc przy tym pod uwagę ich zainteresowania. Niestety zdarza im się także pomijać wiele ważnych z punktu widzenia rozwoju biologicznego i psychospołecznego adolescentów tematów. Niepokój budzi także brak współpracy z innymi nauczycielami w kwestii edukacji seksualnej, ale przede wszystkim brak współdziałania z rodzicami. Nauczyciele powinni rozmawiać z opiekunami uczniów o seksualności ich dzieci, przygotowywać ich na zmiany zachodzące $\mathrm{w}$ ich organizmie, informować ich o zagrożeniach dla pomyślnego rozwoju psychoseksualnego w okresie dorastania, udzielać wskazówek jak rozmawiać z młodzieżą na „trudne” i wstydliwe tematy. Z pewnością wpłynęłoby to pozytywnie na jakość edukacji seksualnej prowadzonej w domu rodzinnym gimnazjalistów i przyczyniło się tym samym do zmniejszenia liczby ryzykownych zachowań seksualnych podejmowanych przez nastolatków. Nauczyciele muszą zdawać sobie sprawę, że tylko wyczerpująca edukacja seksualna, której podmiotami są nie tylko uczniowie, ale także ich rodzice zwiększy szansę na stworzenie przez młodych ludzi szczęśliwych i dojrzałych związków partnerskich. Przyczyni się także do zmiany stereotypów płci, zmiany stosunków do mniejszości seksualnych, poprawy jakości współżycia seksualnego oraz zwiększenia odpowiedzialności za dokonywane czyny ${ }^{34}$.

33 S. Grzelak, Wyspa Skarbów, http://www.remedium-psychologia.p1/2004_8_6.htm, 12.09.2012.

34 E. Kasperek-Golimowska, dz. cyt., s. 102-103. 


\section{Bibliografia}

Teksty źródłowe/akty prawne

[1] Rozporzadzenie Ministra Edukacji Narodowej z 17 lutego 2012 roku zmieniające rozporządzenie w sprawie sposobu nauczania szkolnego oraz zakresu trésci dotyczących wiedzy o życiu seksualnym człowieka, o zasadach świadomego i odpowiedzialnego rodzicielstwa, o wartości rodziny, życia w fazie prenatalnej oraz metodach i środkach świadomej prokreacji zawartych w podstawie programowej kształcenia ogólnego (Dz.U. 2012 nr 0 poz. 300).

\section{Książki/czasopisma}

[2] Augustyn J., Religijny wymiar wychowania seksualnego, „Wychowawca” 2007, nr 7-8.

[3] Baranowska A., Wychowanie seksualne wo szkole - opinie gimnazjalistów , „Nowa Szkoła” 2013, nr 4.

[4] Beisert M., Seksualność w życiu człowieka, Poznań 2003.

[5] Borzucka-Sitkiewicz K., Edukacja seksualna, [w:] E. Syrek (red.), Edukacja zdrowotna, Warszawa 2009.

[6] Długołęcka A., Seksualność - wybrane zagadnienia, [w:] B. Woynarowska (red.), Edukacja zdrowotna. Podręcznik akademicki, Warszawa 2007.

[7] Jósewicz M., Przedszkolaki i seksualność, ,Wychowanie w Przedszkolu” 2007, nr 9.

[8] Kasperek-Golimowska E., Edukacja seksualna jako forma ochrony i promocji zdrowia seksualnego, [w:] K. Waszyńska, Z. Lew-Starowicz (red.), Przemiany seksualności w społeczeństwie wspó́tczesnym: teoria i rzeczywistość, Poznań 2012.

[9] Komorowska-Pudło M., Ważna dziedzina: wychowanie do życia w rodzinie, "Wychowawca" 2008, nr 3.

[10] Kozakiewicz M., Lew-Starowicz Z., Przysposobienie do życia w rodzinie, Warszawa 1987.

[11] Obuchowska I., Jaczewski A., Rozwój erotyczny, Warszawa 1982.

[12] Ozimek E., Jackowiak D., Wychowanie do życia w rodzinie: program nauczania dla klas gimnazjalnych, Warszawa 1999.

[13] Pilch T., Bauman T., Zasady badań pedagogicznych, Warszawa 2001.

[14] Pospiszyl I., Patologie społeczne, Warszawa 2003.

[15] Przetacznik-Gierowska M., Tyszkowa M., Psychologia rozwoju człowieka. Zagadnienia ogólne, T. I, Warszawa 2007.

[16] Sitarska M., Strzemieczna B., Wychowanie do życia w rodzinie (moduł WOS): program nauczania dla klas I-III gimnazjum, Warszawa 2000.

[17] Urban K., Trzy rodzaje edukacji seksualnej, ,,Wychowawca 2007, nr 7-8.

[18] Urban K., Edukacja seksualna ABC, ,"Wychowawca” 2009, nr 4.

[19] Waszyńska K., Biograficzne uzwarunkowania życia seksualnego, Poznań 2009.

Netografia

[20] Grzelak S., Wyspa Skarbów, http://www.remedium-psychologia.pl/2004_8_6.htm, 12.09.2012. 